\title{
Weather as a Competitive Factor between Local and Foreign Manufacturing Companies in Russia
}

\author{
Simo Leppänen ${ }^{1} \cdot$ Svetlana Ledyaeva $^{2} \cdot$ Riitta Kosonen $^{1}$
}

Received: 19 August 2015 / Revised: 25 November 2015

Accepted: 15 December 2015 / Published online: 7 January 2016

(C) The Author(s) 2016. This article is published with open access at Springerlink.com

\begin{abstract}
Globalisation has sparked academic interest in companies' competitive factors and a myriad of internal and external competitive factors have been studied. However, to our knowledge the weather of the host country has not been under study even though weather has been demonstrated to affect economic activity. This paper utilises a company-level panel data to analyse if weather has an impact on domestic and foreign manufacturing companies' operations in Russia. Temperature was identified to have a non-linear effect on foreign companies' revenues, such that a warmer year raises revenues in colder regions while balancing out in warmer regions and actually has a negative effect in the hottest regions. For local Russian companies, we discovered an opposite, but less robust effect. This and home country climate based analysis support the hypothesis that foreign companies benefit from more pleasant weather in the local colder climate while the impact is not so critical for the local companies or foreign companies from countries with similar climate to Russia.
\end{abstract}

Key Words Climate $\cdot$ Weather Competitiveness $\cdot$ Russian regions · Foreign companies Manufacturing $\cdot$ FDI

JEL codes: F21, F23, Q54, R10.

\section{Introduction}

Globalisation has notably intensified in recent decades, which has understandably increased the academic interest in factors of company competitiveness. The different theories and

Simo Leppänen

simo.leppanen@aalto.fi

1 School of Business, Center for Markets in Transition (CEMAT), Aalto University, P.O. Box 21230, FI-00076 AALTO Helsinki, Finland

2 School of Business, Department of Economics, Aalto University, P.O. Box 21240, FI-00076

AALTO Helsinki, Finland 
"schools" of competitiveness literature have been thoroughly discussed in Cater (2005). However, one feature appears to be absent in the competitiveness literature which has investigated various internal (e.g. firms' unique resources, capabilities, and knowledge) and external factors (e.g. new entrants, supplier bargaining power, and host country institutions)namely, weather. Many econometric studies (e.g. Subak et al., 2000; Dell, Jones, \& Olken, 2012) have demonstrated that weather affects economic activity at both the company and national level. However, to our knowledge, weather has not been studied from the competitiveness perspective, even though it is plausible that local companies are better positioned to cope with their local climates.

This study aims to start bridging this gap by empirically examining the weather impacts on revenues of foreign and local manufacturing companies across Russia. Geographically, the country represents an auspicious subject for the topic due to its vast territory and, as a consequence, versatile climatic conditions. Russia consists of Arctic, subarctic, moderate, and subtropical climatic zones, and the average annual temperatures in the western and eastern parts of the country differ by a maximum of $15^{\circ} \mathrm{C}$ between the southwest and northeast corners of Russia (Kotlyakov, 2002). Furthermore, Russia has also global importance in terms of foreign investments: according to the UNCTAD statistics, for example, Russia incorporated $2.4 \%$ of global inward FDI stock in 2010 which was nearly equivalent to Australia's share. Consequently, FDI in Russia has attracted the attention of various academic researchers (e.g. Broadman \& Recanatini, 2001; Ledyaeva, Karhunen, \& Kosonen, 2013; Ledyaeva, Karhunen, Kosonen, \& Whally, 2015).

Our estimations suggest a non-linear temperature effect, such that a warmer year increases foreign companies' revenues in colder regions while balancing out in warmer regions and actually having a negative effect in the hottest regions. Interestingly, this study detected an opposite, but less robust temperature effect for local Russian companies. We hypothesize that benefits to foreign companies from warming arise from the fact that Russia is globally a cold country and this physical difference in the operation environment hampers the operations of companies originating from warmer countries. Warmer weather in Russia brings their operation environment closer to the one they are accustomed to. We found evidence for this deduction by estimating the temperature effect separately for companies from warm and cold countries using several different temperature thresholds.

The paper proceeds as follows. The following section will review the relevant literature and describe our research question. Section 3 describes the compiled data with a presentation of the estimation strategy in section 4 . Section 5 provides the empirical results with conclusions in section 6 .

\section{Literature Review and Research Question}

While research linking foreign companies or competitiveness with weather conditions is nonexistent, there have been several studies which have analysed the weather impacts on different industries. Cachon, Gallino, and Olivares (2012) found that severe weather conditions (defined as extreme weather and periods of intense rain) have had clear negative effects on the production levels of US auto manufacturers. In studying the effect of the exceptionally warm summer of 1995 on UK industries, Subak et al. (2000) identified net positive impacts for energy consumption and health, and negative impacts for building insurance and risk of fires. Similarly, Hsiang (2010) identified that an increase in temperature resulted in a negative effect 
on wholesale and retail trade, other services, mining, and utilities in 28 Caribbean-basin countries. A similar negative growth impact of increased temperature was noticed by Jones and Olken (2010) for developing countries' exports to the US. This effect was negative for 20 light manufacturing industries out of the 66 examined industries; the effect was positive for only two manufacturing industries (dyes and hides). However, they did not find any significant relationship between weather conditions and export growth from rich countries to the US. Finally, Dell et al. (2012) found that higher temperatures produced a negative effect on aggregate economic output in developing countries through, for example, investments and industrial production.

From this literature review, it becomes obvious that weather conditions affect economic activity. These effects can vary from the direct (e.g. heavy seasonal rains, or long, very cold or dry periods which require firms to carry larger inventories due to the difficulty of replenishing stock in inclement weather) to the rather indirect (e.g. workers' productivity might decrease in periods of extreme weather conditions, such as too hot and dry). Thus, it is plausible that the effects of local weather conditions might be more critical for foreign manufacturers than for domestic ones. In particular, domestic manufacturers usually have a long experience of producing in the weather conditions typical for their region while foreign companies require time and resources to adapt to these unfamiliar weather conditions.

We should note that our aim in this paper is not to address the question of firm location, which is a much more studied topic and relates to international business and economic geography literature. For example, in economic geography various theories have been proposed to explain population and company migration patterns and one theory is so called amenity migration according to which people move to areas with high levels of natural amenities such as pleasant climate. Partridge (2010) reviews this literature and concludes that the amenity hypothesis would seem to be the strongest one in explaining the regional migration patterns in the US. Here we are interested in the day-to-day operations of the companies after the location choice is made. Nevertheless, a superficial examination of our data gives some support to the amenity hypothesis as foreign manufacturing companies have clearly concentrated more in warmer regions than their Russian peers (see Fig. 4 in the appendix). On the other hand, it is difficult to distinguish this effect from the "metropolis effect" as it is clear that majority of foreign companies are situated in the Russian metropolis areas which are among the warmer regions within the Russian landscape.

In global terms, Russia is considered quite a cold country, as evidenced in Fig. 1 where Russia's average temperature is contrasted with those of two other large countries, China and the US. While the monthly temperature is on the average very similar in China and the US, it is noticeably lower in Russia from roughly $5^{\circ} \mathrm{C}$ in the summer months to up to $20^{\circ} \mathrm{C}$ in the coldest months. ${ }^{1}$ Cold winter weather has the potential to affect the health and physical safety of workers in manufacturing. In particular, many manufacturing employees work outside and are thus directly exposed to the cold for extended periods of time. In general, cold weather can result in a range of difficulties for those in the manufacturing industry, from increased risk of health problems to machine malfunctions. These difficulties can slow production and provoke injuries and accidents. ${ }^{2}$ From this situation, we derive our basic research hypothesis:

\footnotetext{
${ }^{1}$ In this paper, we will only look at temperature effects, because rainfall is much more difficult to measure accurately and it did not produce significant estimates in our preliminary estimations.

${ }^{2} \mathrm{http} / / /$ www.supplytimes.com/manufacturing/how-cold-weather-affects-manufacturing/?mode=featured
} 


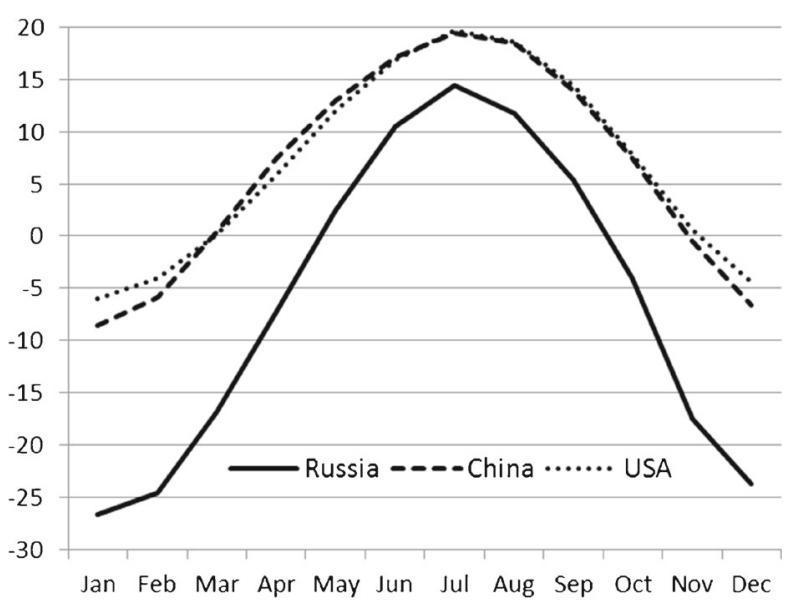

Source: World Bank (2013)

Fig. 1 Average monthly temperature $\left({ }^{\circ} \mathrm{C}\right)$ in 1960-90. Source: World Bank (2013)

Hypothesis: In Russia, a higher temperature is positively associated with the annual revenue fluctuations of foreign manufacturing companies, but it is less important for domestic companies and foreign companies from countries with similar climate to Russia.

\section{Data Description}

Our temperature data is obtained from the web database of the All-Russian Research Institute of Hydro-meteorological Information (meteo.ru) which is funded by the Federal Service for Hydrometeorology and Environmental Monitoring (Roshydromet). For this study we retrieved annual temperatures for the years 20032011 from this database. The weather data was calculated from the weather stations located within each of the regions. Typically, several weather stations were located within the region, and the weather data was averaged from these stations to obtain a regional figure. For the sparsely populated large northern and eastern regions, weather stations were only included if situated relatively close to regional capitals. Weather stations situated at very high altitudes were also excluded. Somewhat surprisingly given Russia's harsh winter, the preliminary estimations found no robust effect for seasonal weather variables, and thus only annual figures were utilised.

The temperature data approach described above leads to an upward bias with respect to pure geographic dimensions as there is a reduction in the weight of the large, cold northern and eastern regions in the weather data. However, the importance of aggregation is not a Russiaspecific question, although it is exacerbated compared to smaller countries. As discussed in Dell, Jones, and Olken (2014), the aggregation decision between geographical and population weighting should be based on the context. This current approach can be considered as largely population-based (due to weather station selection), but it allows a bit more weight for geographical size than pure population-weighted aggregation. Arguably, manufacturing companies are likely to situate relatively close to population centres, because they require labour 


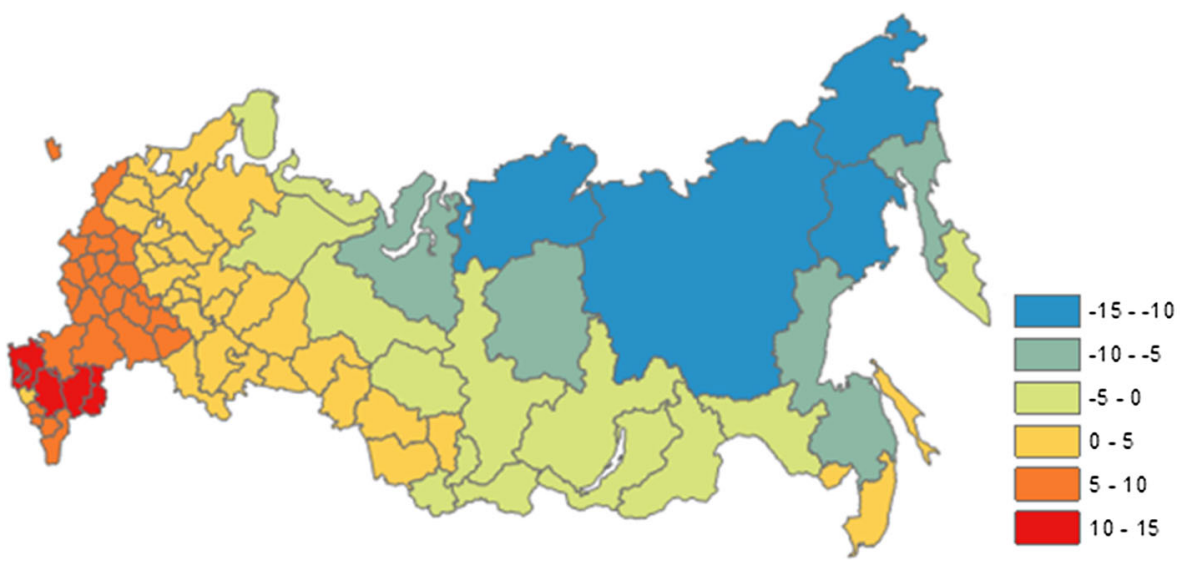

Source: Calculated from the meteo.ru database

Fig. 2 Map of average temperature in Russia by region, ${ }^{\circ} \mathrm{C}$. Source: Calculated from the meteo.ru database

and a close proximity to logistical centres. Thus, the aggregation approach utilised here would seem justified. The data for the mean temperature of the foreign companies' home countries was acquired from World Bank's Climate Change Knowledge Portal (2011).

Figure 2 presents a regional mapping of the average annual temperature across Russia. From the map, a notable difference is observable in the average temperatures between the West and East sides of the Urals. Moreover, the relatively poor Northern Caucasus and South Federal districts in the Southwest corner of Russia can be distinguished as decidedly warmer regions than the rest of Russia.

The company level variables for this study - revenues, employment, and total assets - are taken from the ORBIS database ${ }^{3}$ where the data is available from 2003 onwards. Those firms established by foreign investors from offshore jurisdictions (e.g. Cyprus and Virgin Islands) were excluded, because these investments can be largely considered as round-trip activities by Russian investors (see Ledyaeva et al., 2015). ${ }^{4}$ The regional control variables, besides the temperature, are taken from the Rosstat (Federal State Statistics Service of Russia) database (www.gks.ru) and assessment reports of regional investment potential and risk compiled by the Russian rating agency RA Expert. ${ }^{5}$ Some regions were excluded due to missing data or zero observations leaving 64 geographical regions where foreign companies have located their operations.

\footnotetext{
${ }^{3}$ The ORBIS database of Bureau Van Dijck (BvDEP) is a commercial database which contains comprehensive financial information on around 120 million private companies.

${ }^{4}$ Following Haberly and Wójcik (2013), we utilise an expert agreement definition of tax havens/offshore jurisdictions as jurisdictions appearing at a sufficient percentage (in this study-more than $25 \%$ ) on 11 tax haven lists produced by different researchers (compiled by Palan, Murphy, \& Chavgneux, 2010).

5 www.raexpert.ru; the official website of the Expert Rating Agency $(R A)$, the most respected rating agency in the CIS and Eastern Europe.
} 


\section{Empirical Strategy}

We estimate how weather impacts companies' revenues with the following company level panel fixed effects model $^{6}$ :

$$
y_{j i t}=\beta_{1}+f\left(T_{i t}\right)+\sum_{s} \eta_{s}^{v} Z_{s, j i t}+\sum_{k} \alpha_{k}^{m} X_{k, i t}+\delta_{t}+u_{j}+\gamma_{d t}+\varepsilon_{j i t}
$$

The dependent variable $y_{j i t}$, is the natural logarithm of the gross annual revenues (USD) per employee of company $j$ in region $i$ in year $t$ (2003-2011). ${ }^{7}$ Variable $T$, the annual average temperature in region $i$ in year $t$, is the main variable of interest. Companies situated within the same region share the same temperature data as we do not have information on the exact location of the companies within a region. Under $Z$ we have company level control variables (log of total annual assets per employee and length of experience in Russia) and under $X$ the regional level control variables (market size, market potential, road density, tax level, natural resource potential, investment risk, and institutional potential; see Appendix for details) which are also shared by the firms operating in the same region of Russia. As can be seen from equation (1) the form of the $T$ variable has not been explicitly specified. It has been shown that temperature has a non-linear effect on many variables such as agriculture and health (see e.g. Dell et al., 2014) and thus we test the possibility of a non-linear effect in our case as well. In the results section we report both a linear and quadratic specification of temperature and nonlinearity would seem to play a notable role in our case as well. We include time dummies $\delta_{t}$ to control for unobserved systematic period effects and the firm-level fixed effects $u_{j}$ to control for firm and region specific unobserved time-invariant characteristics (region effects are simultaneously controlled by the firm-level effects as firm's location is a constant characteristic). Industry-by-year dummies $\gamma_{d t}$ control for industry specific periodic shocks. This should control for (among other things) industry-specific temperature effects and thus more credibly suggests that any potential temperature effects truly originate from operation environment differences between the home and the host country. The last term $\varepsilon_{j i t}$ represents an idiosyncratic error term.

The standard errors are clustered regionally which should control for potential spatial autocorrelation. As a fixed effects model is utilised, we identify the weather effect through annual weather variation from the regions' long-term average weather, i.e. typical climate (see Dell et al., 2014 and Seo, 2013 for further discussion on the conceptual difference between weather and climate). To test the competitiveness hypothesis, the model is estimated separately for foreign and Russian owned companies and separately for foreign companies originating from warm and cold countries. Finally, it should be noted that as temperature is clearly an exogenous variable, our model has strong causality properties.

\footnotetext{
${ }^{6}$ Conceptually, our results can be considered as an approximation of what will happen in the future due to climate change ceteris paribus (i.e. without adaptation). Thus, as a side result it provides a sort of benchmark case for climate change impact on companies' revenue development. See Dell et al. (2014) for further conceptual discussion.

${ }^{7}$ It could be argued that profits would be a better dependent variable as it is also available in the ORBIS database. However, the profit (pre-tax) data is highly skewed, and it is problematic to smooth it with a logarithmic transformation as roughly a quarter of the profit observations are negative. Furthermore, there is a notably high spike in small profits or losses even for larger companies potentially suggesting tax optimisation schemes. Thus, we feel that revenues are a more reliable indicator for analysing weather impacts to company operations than profits, at least in the Russian case.
} 


\section{Estimation Results}

Table 1 presents the results for the impact of weather on companies' annual revenues for both foreign and Russian companies. As discussed in the data section, foreign companies from offshore jurisdictions were excluded. This type of investment flow into Russia cannot be classified as real foreign investment, but rather, as asset round-tripping by Russian investors. Also, only companies were included that have an average annual revenue of at least 500000 USD to ensure that the data represent companies with proper manufacturing activities. For robustness, a sample with average annual revenues between 500 thousand and 16 million USD was also utilised thus excluding the largest companies' revenues (dropping roughly $30 \%$ of high-end observations). The regressions were also calculated with data excluding the metropolitan areas (Table 2) as the bulk of foreign companies (roughly half of observations) are situated in the Russian metropolitan areas (Moscow and St. Petersburg and their immediate surroundings) and for firms originating from warm and cold countries (Table 3). All of these estimations include a full set of control variables and fixed company effects, year dummies and industry-year dummies, but these are not explicitly presented in the tables to save space (available upon request).

As can be seen in Table 1, the linear specification would suggest that temperature does not have any effect on companies' revenues. However, if temperature is modelled quadratically, a clear temperature effect is observed for foreign companies and the result is robust if largest firms are excluded. The estimate suggests that annual company revenue increases strongly when temperature increases in colder regions while the effect stabilises in warmer regions and turns negative in the hottest regions. The result is intuitive in the sense that foreign companies would benefit from warmer than usual weather in Russia's relatively cold climate, but this effect is smaller for firms operating in Russia's warmer regions, and warming is detrimental for companies in the hottest regions. Table 2 illustrates the same regressions with data excluding metropolitan areas. The non-linearity of temperature seems to be robust.

Table 1 Determinants of companies' revenues, panel data results, equation (1), all regions

\begin{tabular}{|c|c|c|c|c|c|}
\hline & & $\begin{array}{l}\text { (1) Revenue: } \\
>500 \text { k USD } \\
f(T) \text { : linear }\end{array}$ & $\begin{array}{l}\text { (2) Revenue: } \\
>500 \text { k USD } \\
f(T) \text { : quadratic }\end{array}$ & $\begin{array}{l}\text { (3) Revenue: } \\
500 \mathrm{k}-16 \mathrm{mln} \text { USD } \\
f(T) \text { : linear }\end{array}$ & $\begin{array}{l}\text { (4) Revenue: } \\
500 \mathrm{k}-16 \mathrm{mln} \\
\text { USD } f(T) \text { : quadratic }\end{array}$ \\
\hline \multirow[t]{5}{*}{ Foreign firms } & Temperature & 0.065 & $0.177 * * *$ & 0.067 & $0.158 * *$ \\
\hline & & $(0.048)$ & $(0.065)$ & $(0.060)$ & $(0.079)$ \\
\hline & Temperature $^{2}$ & & $-0.011 * * *$ & & $-0.010^{* *}$ \\
\hline & & & $(0.004)$ & & $(0.004)$ \\
\hline & $R^{2}$ (within) & 0.32 & 0.32 & 0.24 & 0.25 \\
\hline \multirow[t]{5}{*}{ Russian firms } & Temperature & -0.037 & $-0.126^{*}$ & 0.027 & -0.035 \\
\hline & & $(0.045)$ & $(0.073)$ & $(0.058)$ & $(0.069)$ \\
\hline & Temperature $^{2}$ & & $0.009 * *$ & & $0.007 * *$ \\
\hline & & & $(0.004)$ & & $(0.003)$ \\
\hline & $R^{2}$ (within) & 0.24 & 0.24 & 0.27 & \\
\hline \multicolumn{2}{|c|}{ Observations (Warm; cold) } & $4492 ; 3342$ & $4492 ; 3342$ & $2935 ; 1942$ & $2935 ; 1942$ \\
\hline
\end{tabular}

1) $*$ if $p<0.10, * *$ if $p<0.05 ; * * *$ if $p<0.01$; 2) Clustered standard errors in parentheses; 3) all estimations include time dummies 
Table 2 Weather effect on companies' revenues, panel data results, equation (1), metropolitan areas excluded

\begin{tabular}{|c|c|c|c|c|c|}
\hline & & $\begin{array}{l}\text { (1) Revenue: } \\
>500 \text { k USD } \\
f(T) \text { : linear }\end{array}$ & $\begin{array}{l}\text { (2) Revenue: } \\
>500 \text { k USD } \\
f(T) \text { : quadratic }\end{array}$ & $\begin{array}{l}\text { (3) Revenue: } \\
500 \mathrm{k}-16 \text { mln USD } \\
f(T) \text { : linear }\end{array}$ & $\begin{array}{l}\text { (4) Revenue: } \\
500 \mathrm{k}-16 \mathrm{mln} \\
\text { USD } f(T) \text { : quadratic }\end{array}$ \\
\hline \multirow[t]{5}{*}{ Foreign firms } & Temperature & 0.082 & $0.187 * * *$ & $0.084 *$ & $0.172 * *$ \\
\hline & & $(0.056)$ & $(0.070)$ & $(0.069)$ & $(0.083)$ \\
\hline & Temperature $^{\wedge} 2$ & & $-0.011 * * *$ & & $-0.010^{* *}$ \\
\hline & & & $(0.004)$ & & $(0.004)$ \\
\hline & $R^{2}$ (within) & 0.30 & 0.30 & 0.26 & 0.27 \\
\hline \multirow[t]{5}{*}{ Russian firms } & Temperature & $-0.073 *$ & $-0.164 * *$ & -0.036 & -0.096 \\
\hline & & $(0.040)$ & $(0.071)$ & $(0.048)$ & $(0.063)$ \\
\hline & Temperature $^{\wedge} 2$ & & $0.010^{* *}$ & & $0.007 * *$ \\
\hline & & & $(0.004)$ & & $(0.003)$ \\
\hline & $R^{2}$ (within) & 0.34 & 0.34 & 0.33 & \\
\hline \multicolumn{2}{|c|}{ Observations (Foreign; Russian) } & $2207 ; 2583$ & $2207 ; 2583$ & $1479 ; 1496$ & $1479 ; 1496$ \\
\hline
\end{tabular}

Notes similar to Table 1

Interestingly for Russian companies, the temperature effect is reversed compared to foreign companies, although less robustly so. There is no clear intuition for this relation suggesting that turnover of Russian firms increase in warmer years in the warmer regions and decline in the colder regions. One economic explanation would be that the competitive edge of warmer temperatures for foreign companies overwhelms the competitiveness of local companies. This would support our hypothesis and actually take it one step further, indicating that warmer weather would benefit foreigners so much that local producers suffer. However, we feel that based on the evidence at hand, this might be making too strong of a conclusion on the impact of temperature.

Table 3 Weather effect on companies' revenues, panel data results, equation (1), warm vs. cold country firms

\begin{tabular}{|c|c|c|c|c|c|c|}
\hline & & $\begin{array}{l}\text { (1) } \\
\text { Threshold } \\
\text { temperature } \\
5^{\circ} \mathrm{C}\end{array}$ & $\begin{array}{l}(2) \\
\text { Threshold } \\
\text { temperature } \\
6^{\circ} \mathrm{C}\end{array}$ & $\begin{array}{l}\text { (3) } \\
\text { Threshold } \\
\text { temperature } \\
7{ }^{\circ} \mathrm{C}\end{array}$ & $\begin{array}{l}\text { (4) } \\
\text { Threshold } \\
\text { temperature } \\
8^{\circ} \mathrm{C}\end{array}$ & $\begin{array}{l}\text { (5) } \\
\text { Threshold } \\
\text { temperature } \\
9^{\circ} \mathrm{C}\end{array}$ \\
\hline \multirow{5}{*}{$\begin{array}{l}\text { Warm country } \\
\text { firms }\end{array}$} & Temperature & $0.230 * * *$ & $0.230 * *$ & $0.237 * *$ & $0.246 * *$ & $0.274 * *$ \\
\hline & & $(0.089)$ & $(0.089)$ & $(0.099)$ & $(0.106)$ & $(0.132)$ \\
\hline & Temperature $^{\wedge} 2$ & $-0.015 * * *$ & $-0.016^{* * *}$ & $-0.017 * * *$ & $-0.012 * * *$ & $-0.019 * *$ \\
\hline & & $(0.005)$ & $(0.005)$ & $(0.006)$ & $(0.006)$ & $(0.009)$ \\
\hline & $R^{2}$ (within) & 0.17 & 0.17 & 0.17 & 0.19 & 0.23 \\
\hline \multirow[t]{5}{*}{ Cold country firms } & Temperature & -0.079 & -0.041 & 0.080 & 0.104 & $0.145^{*}$ \\
\hline & & $(0.163)$ & $(0.156)$ & $(0.095)$ & $(0.094)$ & $(0.078)$ \\
\hline & Temperature $^{\wedge} 2$ & 0.000 & -0.001 & -0.006 & -0.008 & $-0.011 * *$ \\
\hline & & $(0.011)$ & $(0.010)$ & $(0.007)$ & $(0.007)$ & $(0.004)$ \\
\hline & $R^{2}$ (within) & 0.17 & 0.18 & 0.19 & 0.15 & 0.15 \\
\hline \multicolumn{2}{|c|}{ Observations (warm; cold) } & $3619 ; 873$ & $3505 ; 987$ & $2813 ; 1679$ & $2679 ; 1813$ & $1594 ; 2898$ \\
\hline
\end{tabular}

Notes similar to Table 1 
One could argue that the differences by ownership could arise from different geographical distribution as the companies have clearly located differently by temperature (see Fig. 4 in the appendix). We tested this by excluding companies from the largest temperature bin and the results (Table 7 in the appendix) are quite similar to Table 2 thus mainly reflecting the "metropolis effect" because both metropolis regions are situated within that same temperature bin (mean annual temperature for the Moscow metropolis area is $5.7^{\circ} \mathrm{C}$ and $5.0{ }^{\circ} \mathrm{C}$ for St. Petersburg).

Also, it is possible that the size of the company could be the reason behind the different temperature effect if Russian and foreign companies are of different size. There is some merit to this argument as we do not have a direct control for company size in our model even though company fixed effects should roughly control for this and the statistical size distribution is not very different for Russian and foreign companies (see Table 5 in the Appendix). We tested the size argument by running the estimations separately for three firm groups consisting of the three highest quartiles of average turnover for the whole period including both the foreign and Russian firms (the lowest quartile was excluded as it consists mostly firms smaller than our 500 thousand USD threshold). We did not find any significant temperature effects from linear or quadratic specifications suggesting that firm size is not the mechanism behind the temperature effect (results available upon request).

Figure 3 was produced to visualise the results of the non-linear temperature effect on foreign companies. The figure shows the shape of the quadratic temperature function $f(T)$ and the actual impact $\beta$ (which is simply the derivative of the function) in regions with different temperatures based on results in Table 1 . The impact is quite strong in the coldest areas, up to around 30 (indicating a $30 \%$ increase in revenues if temperature is $1{ }^{\circ} \mathrm{C}$ higher). However, it should be noted that only ten per cent of the regions have an average temperature below $+2{ }^{\circ} \mathrm{C}$, and subsequently, the effect is much milder for most of the regions. The temperature effect becomes negative in the hottest regions topping $8{ }^{\circ} \mathrm{C}$ annual average temperature beyond which roughly ten per cent of all regions are also situated. We also include the mean temperature for Russian regions $\left(5.2^{\circ} \mathrm{C}\right.$ in our data) in Fig. 3 to give a reference point of the temperature effect in an average temperature region.

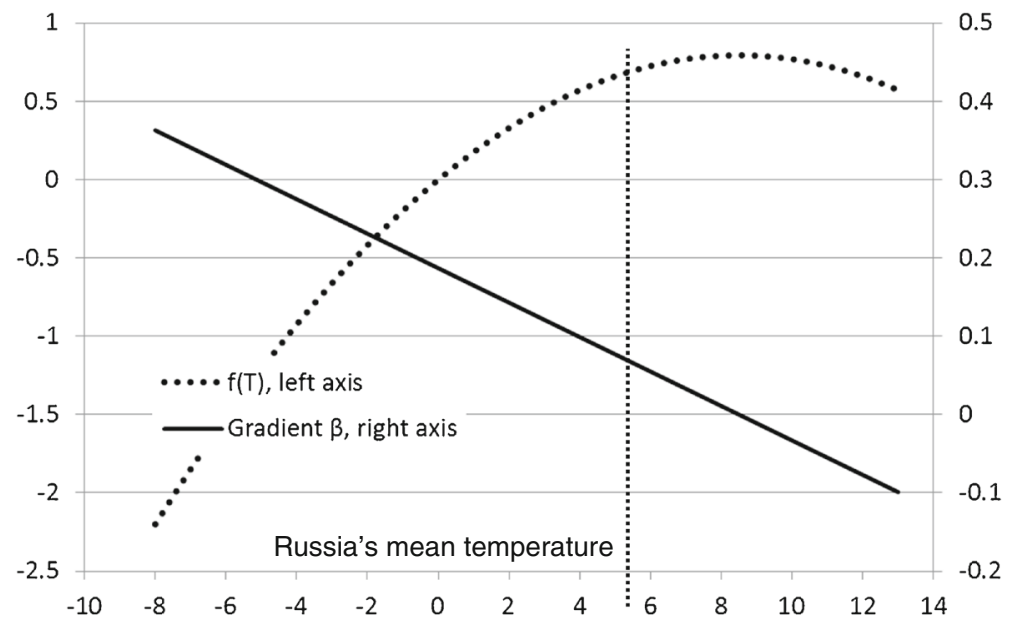

Fig. 3 Temperature effects of equation (1), (left axis, the effect function $\mathrm{f}(\mathrm{T})$; right axis, the size of the temperature change effect, " $\beta$ ", at different regional temperature level); $\mathrm{x}$-axis, annual regional temperature ${ }^{\circ} \mathrm{C}$ 
Finally, we run additional analysis to search support to our hypothesis that difference in home and host country climate is behind the results obtained above. We do this by running similar estimations separately for colder and warmer countries operating in Russia (Russian companies excluded from the analysis). The problem is that there are differences, as discussed earlier, in how to calculate temperature. The pure geographic approach might not represent the climate experienced by most companies especially in large countries such as Canada, China and the US where manufacturing companies are situated near population centres. Additional problem is that we do not have information on the exact home location of the foreign firms, which might make a difference for firms originating from large countries. This might create notable inaccuracies if we were to directly analyse the temperature differences between companies' home country and operation region in Russia. Thus, we do a rougher but arguably less sensitive analysis where we estimate equation (1) separately for firms coming from cold and warm countries using five different temperature thresholds between $5-9{ }^{\circ} \mathrm{C}$ (those being below the threshold defined as cold and those above as warm). The limits of the thresholds are determined by amount of available data, below $5{ }^{\circ} \mathrm{C}$ and above $9{ }^{\circ} \mathrm{C}$ would be only few hundred observations which is quite little for such a complex model. The results are presented in Table 3, temperature was not significant in any of linear models thus we report only the quadratic models here.

From Table 3 we can see that the results support our hypothesis. If we use data from warm countries we again find the inverse $\mathrm{U}$-shape relation while no significant relation is to be found for firms originating from cold countries (from countries where mean temperature is below $8^{\circ} \mathrm{C}$ ). Thus firms from cold countries do not benefit from additional warmth in their operating regions while firms from warm countries do benefit up to a point. The maximum of the inverse U-shape relation is obtained around $7-10{ }^{\circ} \mathrm{C}$ depending of the temperature threshold used. This suggests that even warm country originated companies operating in Russian regions warmer than $7-10^{\circ} \mathrm{C}$ are not benefiting from additional warmth or are even suffering from it. Also the positive coefficient of the linear term is larger for the warm country firms the higher the used home country temperature threshold is. This suggests that the warmer the firm's home country is, the warmer is a region it can locate into and still reap benefits from additional warmth. These results are intuitive in the framework of our hypothesis in the sense that warm year is more beneficial the larger the difference is between the home and host country climate. As can be seen in the last column of Table 3 similar quadratic effect appears also for cold countries although as clearly flatter. This effect is probably due to Germany as its firms now enter the cold regions group and it has a notable share of the companies in the data.

\section{Conclusions}

In this study, we argue that familiarity with local climate is a competitive edge for domestic companies compared to foreign companies, especially in countries with a harsh climate. We utilise Russian firm-level manufacturing industry data to study this issue as Russia has a very versatile climate and is globally a relatively important FDI destination. More specifically, we study if weather has an impact on foreign companies' annual revenues and if this impact is different for Russian companies and use firms' home country climate based estimations to deduct the origin of these differences.

We identify a rather robust quadratic (concave) effect of local temperature on foreign companies' revenues. The effect was remarkably similar when using full data, or alternatively 
data excluding the largest companies or metropolitan areas which inhabit roughly half of the observations. In particular, our results suggest that foreign companies' revenues are higher in warmer years in colder Russian regions while the effect evens out in warmer regions and actually turns negative for firms operating in the hottest regions. For Russian companies, we found rather interestingly an opposite but less robust temperature effect. We hypothesized that benefits from warming accrue to foreign companies due to the fact that Russia is generally quite a cold country and this hampers the operational abilities of companies originating from warmer countries. Thus warmer weather in Russia brings their operation environment closer to the one they are accustomed to. We found evidence for this conclusion by estimating the impact separately for companies from warm and cold countries using several different temperature thresholds for robustness. Thus, there seems to be evidence that weather is a competitive factor for companies, at least in Russia - where discussion has centred on institutions - and it might increase in importance if climate change intensifies as forecasted by the IPCC (2014).

Acknowledgments Authors gratefully acknowledge the financing from the Academy of Finland (the grant No 255635) and valuable comments from the participants of the ENRMDTE 2014 Conference.

\section{Appendix}

Table 4 Control variables in specification (1): Description and data sources

\begin{tabular}{|c|c|c|}
\hline Variable & Description & Data sources \\
\hline Market size of a Russian region & $\begin{array}{l}\text { It is measured by the first principal component of three } \\
\text { variables (gross regional product, total population, and } \\
\text { population density) for a particular region } i(i=1, \ldots, 76) \text {, in } \\
\text { a given year, } t-1(t=2003-2011) \text {. This indicator for the } \\
\text { market size in Russian regions was introduced in a study by } \\
\text { Iwasaki and Suganuma (2005). The proportion of variance } \\
\text { of the first component can reach } 80 \% \text {, and its eigenvector } \\
\text { and component loading show that this variable is suitable as } \\
\text { a general index of market size. }\end{array}$ & Rosstat \\
\hline $\begin{array}{l}\text { Market size of neighbouring } \\
\text { regions of a Russian region }\end{array}$ & $\begin{array}{l}\text { It is defined as the sum of the market sizes (measured using the } \\
\text { Market variable) of the surrounding regions within a } \\
\text { distance of } 500 \mathrm{~km} \text { (between the capital of a particular } \\
\text { Russian region and the capital of a neighbouring (but not } \\
\text { necessarily bordering) region). This distance threshold } \\
\text { between neighbouring regions has been chosen based on } \\
\text { the "trial-and-error" method. }\end{array}$ & Rosstat \\
\hline $\begin{array}{l}\text { Roads density in a Russian } \\
\text { region }\end{array}$ & $\begin{array}{l}\text { It reflects the regional development of railways and highways } \\
\text { and is measured by the average density of railways and } \\
\text { highways in a particular region, } i(i=1, \ldots, 76) \text {, in a given } \\
\text { year, } t-1 \text { ( } t=2003-2011) \text { (where data is not available-for } \\
\text { the nearest year). }\end{array}$ & Rosstat \\
\hline
\end{tabular}

Tax level in a Russian region

It is measured by the ratio of regional tax revenues to gross regional product for a particular region, $i(i=1, \ldots, 76)$, in a given year, $t-1(t=2003-2011)$.

Resource potential in a Russian It is measured using an online Expert $R A$ journal $^{\mathrm{a}}$ ranking $^{\mathrm{b}}$ for region

a particular region, $i(i=1, \ldots, 76)$, in a given year, $t-1$ ( $t=2003-2011$ ) (from 1 to 89: 1 corresponds to the highest

Rosstat

Online Expert $R A$ journal 
Table 4 (continued)

\begin{tabular}{|c|c|c|}
\hline Variable & Description & Data sources \\
\hline & $\begin{array}{l}\text { potential and } 89 \text { corresponds to the lowest potential). This } \\
\text { indicator reflects the average weighted availability of } \\
\text { balanced stocks of principal natural resources in the Russian } \\
\text { regions. }\end{array}$ & \\
\hline $\begin{array}{l}\text { Institutional potential in a } \\
\text { Russian region }\end{array}$ & $\begin{array}{l}\text { It is an online Expert } R A \text { journal ranking ranging from } 1 \text { to } 89 \\
\text { for a particular Russian region, } i(i=1, \ldots, 76) \text {, in a given } \\
\text { year, } t-1(t=2003-2011)(1 \text { is assigned to a region with the } \\
\text { highest potential in Russia, and } 89 \text { is assigned to a region } \\
\text { with the lowest potential). This indicator reflects the level of } \\
\text { development of principal market institutions in the Russian } \\
\text { regions. }\end{array}$ & $\begin{array}{c}\text { Online Expert } \\
R A \text { journal }\end{array}$ \\
\hline $\begin{array}{l}\text { Investment risk in a Russian } \\
\text { region }\end{array}$ & $\begin{array}{l}\text { It is an online Expert } R A \text { journal ranking ranging from } 1 \text { to } 89 \\
\text { for a particular Russian region, } i(i=1, \ldots, 76) \text {, in a given } \\
\text { year, } t-1 \text { ( } t=2003-2011)(1 \text { is assigned to a region with the } \\
\text { smallest risk in Russia, and } 89 \text { is assigned to a region with } \\
\text { the largest risk). This is a qualitative indicator that } \\
\text { simultaneously reflects political, economic, social, criminal, } \\
\text { financial, ecological, and legislative risks for investment } \\
\text { activities in the Russian regions. }\end{array}$ & $\begin{array}{c}\text { Online Expert } \\
R A \text { journal }\end{array}$ \\
\hline $\begin{array}{l}\text { Corruption level in a Russian } \\
\text { region }\end{array}$ & $\begin{array}{l}\text { It is measured by the corruption dimension of the Index of } \\
\text { Democracy provided by the Moscow Carnegie Center for } \\
\text { the period 2000-2004 (on average; yearly data is not } \\
\text { available). It is measured on a 5-point scale, where } 1 \\
\text { indicates the highest level of corruption and } 5 \text { the lowest. } \\
\text { This indicator refers mainly to public sector corruption in a } \\
\text { broader sense, that is, the interconnections between political } \\
\text { and business elites and their interventions in the political } \\
\text { decision-making process. }\end{array}$ & $\begin{array}{l}\text { Moscow } \\
\text { Carnegie } \\
\text { Center }\end{array}$ \\
\hline Experience in Russian markets & $\begin{array}{l}\text { It is the proxy for experience in Russian markets. For each } \\
\text { year and region, it gets a value based on how early } \\
\text { (calculating from 2003) the data is available for the } \\
\text { company. The proxy is somewhat suboptimal as some firms } \\
\text { have operated in Russia already before } 2003 \text { (thus the } \\
\text { variable is truncated at a maximum of nine years), but this is } \\
\text { the best proxy available from the data. }\end{array}$ & $\begin{array}{l}\text { ORBIS } \\
\text { database }\end{array}$ \\
\hline
\end{tabular}

\footnotetext{
${ }^{a}$ http://www.raexpert.ru/ - the official webpage of Expert Rating Agency $(R A)$, the most respected rating agency in the CIS and Eastern Europe

${ }^{\mathrm{b}}$ This indicator reflects the average weighted availability of balanced stocks of principal natural resources in the Russian regions
} 
Table 5 Descriptive statistics of the variables

\begin{tabular}{llllll}
\hline Variable & Obs. & Mean & Std. Dev. & Min & Max \\
\hline Foreign companies & & & & & \\
Ln(revenues per employee) & 4502 & 4.0 & 1.6 & -7.7 & 11.9 \\
Temperature (annual) & 9261 & 5.2 & 2.4 & -8.9 & 13.8 \\
Ln(total assets per employee) & 4495 & 4.1 & 1.6 & -1.8 & 12.1 \\
Experience & 9270 & 2.3 & 2.8 & 0.0 & 9.0 \\
Market Size & 9261 & 3.7 & 5.0 & -0.9 & 16.3 \\
Market Potential & 9261 & 1.6 & 5.8 & -6.7 & 23.1 \\
Roads & 9261 & 313.6 & 180.1 & 1.6 & 623.5 \\
Tax & 9261 & 0.1 & 0.0 & 0.0 & 0.5 \\
Natural Resources & 9261 & 59.1 & 25.4 & 1.0 & 89.0 \\
Institutions & 9261 & 15.1 & 18.1 & 1.0 & 78.0 \\
Risk & 9261 & 22.0 & 18.9 & 1.0 & 76.0 \\
Russian companies & & & & & \\
Ln(revenues per employee) & 3663 & 3.9 & 1.6 & -6.8 & 11.9 \\
Temperature (annual) & 5643 & 5.1 & 3.0 & -8.9 & 13.8 \\
Ln(total assets per employee) & 3644 & 3.8 & 1.7 & -1.8 & 12.1 \\
Experience & 3663 & 2.9 & 2.9 & 0.0 & 9.0 \\
Market Size & 5643 & 1.9 & 3.9 & -0.9 & 16.3 \\
Market Potential & 5643 & 2.3 & 5.3 & -6.7 & 23.1 \\
Roads & 5643 & 234.3 & 161.6 & 1.6 & 623.5 \\
Tax & 5639 & 0.1 & 0.0 & 0.0 & 0.2 \\
Natural Resources & 5643 & 46.9 & 25.5 & 1.0 & 89.0 \\
Institutions & 5643 & 19.5 & 18.0 & 1.0 & 79.0 \\
Risk & 5643 & 26.9 & 19.7 & 1.0 & 76.0 \\
\hline
\end{tabular}

Table 6 Industry structure by ownership in the data

\begin{tabular}{lllll}
\hline & \multicolumn{2}{l}{ Russian companies } & \multicolumn{2}{l}{ Foreign companies } \\
\hline Industry & Count & Share, \% & Count & Share, \% \\
Food & 143 & 23 & 131 & 13 \\
Textiles & 10 & 2 & 46 & 4 \\
Forest & 32 & 5 & 121 & 12 \\
Coke, petroleum, plastic, chemicals & 189 & 30 & 273 & 27 \\
Metals and metal products & 85 & 14 & 114 & 11 \\
Machines and electronic products & 110 & 18 & 249 & 24 \\
Vehicles & 45 & 7 & 66 & 6 \\
Other & 14 & 2 & 30 & 3 \\
Total & 628 & 100 & 1030 & 100 \\
\hline
\end{tabular}




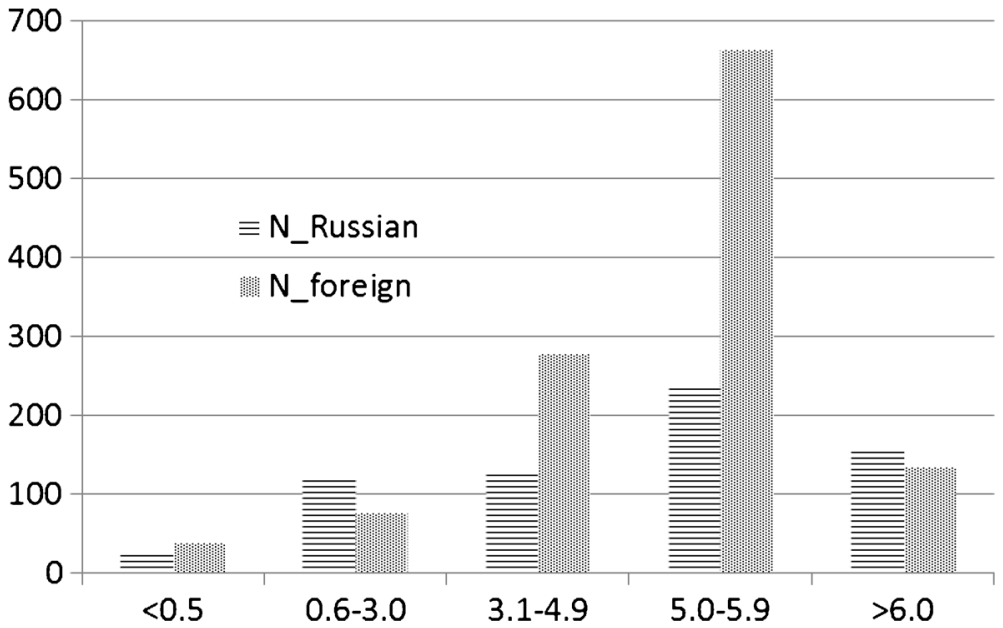

Fig. 4 Distribution of companies by regional temperature, $x$-axis is mean regional temperature, $y$-axis number of Russian and foreign companies in the data

Table 7 Weather effect on companies' revenues, panel data results, equation (1), regions with mean temperature of 5-5.9 ${ }^{\circ} \mathrm{C}$ excluded

\begin{tabular}{|c|c|c|c|c|c|}
\hline & & $\begin{array}{l}\text { (1) Revenue: } \\
>500 \text { k USD } \\
f(T) \text { : linear }\end{array}$ & $\begin{array}{l}\text { (2) Revenue: } \\
>500 \text { k USD } \\
f(T) \text { : quadratic }\end{array}$ & $\begin{array}{l}\text { (3) Revenue: } \\
500 \mathrm{k}-16 \text { mln USD } \\
f(T) \text { : linear }\end{array}$ & $\begin{array}{l}\text { (4) Revenue: } \\
500 \mathrm{k}-16 \mathrm{mln} \\
\text { USD } f(T) \text { : quadratic }\end{array}$ \\
\hline \multirow[t]{5}{*}{ Foreign firms } & Temperature & 0.053 & $0.165^{* *}$ & 0.056 & $0.160^{*}$ \\
\hline & & $(0.060)$ & $(0.077)$ & $(0.078)$ & $(0.104)$ \\
\hline & Temperature $^{\wedge} 2$ & & $-0.012^{* * *}$ & & $-0.012 * *$ \\
\hline & & & $(0.004)$ & & $(0.005)$ \\
\hline & $R^{2}$ (within) & 0.30 & 0.30 & 0.26 & 0.27 \\
\hline \multirow[t]{5}{*}{ Russian firms } & Temperature & -0.064 & $-0.155^{* *}$ & -0.012 & -0.072 \\
\hline & & $(0.044)$ & $(0.076)$ & $(0.054)$ & $(0.073)$ \\
\hline & Temperature $^{\wedge} 2$ & & $0.010^{* *}$ & & $0.006^{*}$ \\
\hline & & & $(0.004)$ & & $(0.003)$ \\
\hline & $R^{2}$ (within) & 0.35 & 0.35 & 0.35 & 0.35 \\
\hline \multicolumn{2}{|c|}{ Observations (Foreign; Russian) } & $1637 ; 2136$ & $1637 ; 2136$ & $1105 ; 1240$ & $1105 ; 1240$ \\
\hline
\end{tabular}

Notes similar to Table 1 
Open Access This article is distributed under the terms of the Creative Commons Attribution 4.0 International License (http://creativecommons.org/licenses/by/4.0/), which permits unrestricted use, distribution, and reproduction in any medium, provided you give appropriate credit to the original author(s) and the source, provide a link to the Creative Commons license, and indicate if changes were made.

\section{References}

Broadman H, Recanatini F (2001) Where has all the foreign investment gone in Russia? Policy research working paper No. 2640. World Bank, Washington, DC

Cachon G, Gallino S, Olivares M (2012). Severe weather and automobile assembly productivity. Columbia Business School Research Paper No. 12/37

Cater T (2005) Interweaving of the sources and forms of a firm's competitive advantage: a critical review of the adequacy of existing schools of thought. J East Eur Manag Stud 10:1

Dell M, Jones BF, Olken BA (2012) Temperature shocks and economic growth: evidence from the Last Half century. Am Eco J Macroecon 4(3):66-95

Dell M, Jones, BF, Olken, BA (2014) What do we learn from the weather? the new climate-economy literature. J Econ Lit 52(3):740-798

Haberly D, Wójcik D (2013) Tax havens and the production of offshore FDI: an empirical analysis, SSRN: http:// papers.ssrn.com/sol3/papers.cfm?abstract_id=2252431

Hsiang SM (2010) Temperatures and cyclones strongly associated with economic production in the Caribbean and Central America. Proc Natl Acad Sci 107(35):15367

IPCC - Intergovernmental Panel on Climate Change (2014) The fifth assessment report AR 5 - The Physical Science Basis

Iwasaki I, Suganuma K (2005) Regional distribution of Foreign Direct Investment in Russia. Post-Communist Econ 17(2):153-172

Jones BF, Olken BA (2010) Climate shocks and exports. Am Econ Rev Pap Proc 100(2010):454-459

Kotlyakov, V. 2002. Russia's climate - description. Land resources of Russia CD-ROM - The International Institute for Applied Systems Analysis (IIASA)

Ledyaeva S, Karhunen P, Kosonen R (2013) Birds of a feather: evidence on commonality of corruption and democracy in the origin and location of foreign investment in Russian regions. Eur J Polit Econ 32:1-25

Ledyaeva S, Karhunen P, Kosonen R, Whally J (2015) Offshore FDI, capital round-tripping, and corruption: empirical analysis of Russian regions. Econ Geogr 91(3):305-341

Palan R, Murphy R, Chavgneux C (2010) Tax Havens: How Globalization Really Works. Cornell University press, Ithaca

Partridge MD (2010) The duelling models: NEG vs amenity migration in explaining US engines of growth. Pap Reg Sci 89(3):513-536

Seo SN (2013) An essay on the impact of climate change on US agriculture: weather fluctuations, climatic shifts, and adaptation strategies. Clim Chang 121(2):115-124

Subak S, Palutikof JP, Agnew MD, Watson SJ, Bentham CG, Cannell MGR, Hulme M, McNally S, Thornes JE, Waughray D, Woods JC (2000) The impact of the anomalous weather of 1995 on the U.K. economy. Clim Chang 44(1-2):1-26

World Bank (2011, Database updated) Climate change knowledge portal: Historical Data. http://data.worldbank. org/data-catalog/cckp_historical_data

World Bank (2013, Data retrieved) Climate change knowledge portal. http://sdwebx.worldbank.org/ climateportal/index.cfm 